\title{
Great Expectations, Now that My Special Olympics Hero Got His Own Daughter
}

\author{
Jiaying Shen
}

\section{Interview with Mr. Fangmiao Wu and His Family}

Fangmiao Wu, male, born in 1988. The only child in his family. Grade IV intellectual disability. Graduated from a special school-Shanghai Yangfan School in 2007. Employed by a Sunshine Workshop in Pudong New District of Shanghai in 2009.

Interviewee: Fangmiao Wu, Guixin Wu (father), Ruiying Fang (mother), Ruicai Li (wife)

Interviewer and writer: Jiaying Shen

Interview dates: October 30 and December 17, 2016

Interview place: Wu's home

\section{Finally Able to Walk at Seven}

Q: Could you tell me, Mom and Dad, when you came to know each other and get married?

Mother: Right after we graduated from school, so it started on January 1, 1982, and we got married in 1987.

Q: Oh, 5 years, so not that quick.

Mother: Without our own house at the time, the conditions were not right for us to get married. Even when we were ready for marriage, we still had no house. Then we thought that since we had been together for a long time, why not just get married and simply live in my mom's place. Our family lived in a unit among the so-called

On July 20, 2007, after Fangmiao Wu participated in China Dragon TV's Program Go for Special Olympics! Cheers for Heroes! many media outlets started to address Fangmiao Wu as "My Special Olympics Hero". Related media coverage included "Touching Interactions between Fangmiao Wu, My Special Olympics Hero, and Boran Jing" at Sohu Sports and more.

J. Shen $(\bowtie)$

Fudan University, 220 Handan Ro, Shanghai 200433, China 
"Twenty Thousand Households."1 My uncle and my brother lived in the front room of the unit and we lived in the rear room. Units in "Twenty Thousand Households" were all old houses where kitchens and bathrooms were shared among every five households.

Q: What did you do for a living?

Mother: His father originally worked at Shanghai Machine Tool Works, and later he resigned because the company didn't make much money. He resigned on December 27, 2009, and then went out to work again 10 years later; living expenses were high for us with Fangmiao Wu at that time. As for me, I worked at the state-owned No. 12 Cotton Mill, and wages were low. I have been working since retirement till now. Alas, Fangmiao Wu only makes a few hundred yuan at the Sunshine Workshop, not enough for him to raise his child, so we have to work harder. From this year onward, people like him with disabilities can receive subsistence allowances of 300 yuan a month. There's also a child support subsidy, which is for his daughter. His wife is not a local Shanghainese, and has not done any work before, so she has no social insurance. Now us parents from both sides are working to raise this child together. Oh, we have no other choice.

Q: After you got married, when was Fangmiao Wu born? According to a news report, Fangmiao Wu was choked with amniotic fluid?

Mother: We got married on November 7, 1987, and Fangmiao Wu was born on May 16, 1988. Yes, he was choked with amniotic fluid. Fangmiao Wu was delivered to me on May 16 after midnight at three o'clock.

Father: Delivered at 3:15.

Mother: I had no idea what to do at that time. I just felt rather uncomfortable. I thought maybe I was going to deliver the baby soon, so I sat up and called for the doctor. There were no bells at the bedside in hospital in those days, so you had to go for the doctor if anything came up. It was 3 o'clock. However, my water actually broke at 2:30, and I sat up. The doctor later said I shouldn't have sat up. When giving me treatment, the doctor said, "Your water choked the baby."

Wu: When I was born, my face was purple.

Q: Was intellectual disability identified in the test at first?

Mother: I had no idea then, as it was a natural birth. When I asked the doctor about the baby, he said the baby was okay. I thought things were fine then, and I was discharged from the hospital 4 days later. However, Fangmiao Wu was not discharged with me. According to the doctor, "The face of your child was red as blood, as if having drunk wine." As a matter of fact, it was the result of being choked with amniotic fluid, but at that time we didn't know. They said he had to be kept in

\footnotetext{
${ }^{1}$ In 1952, in order to solve the housing problems of workers, the Shanghai government launched the project of 20,000 residential units for workers, commonly known as the "Twenty Thousand Households" project, through which 20,000 homes were built for workers in the east of Shanghai, the west of Shanghai, and on the edge of the Industrial Zone in the south of Shanghai. With a brick and wood structure, a building for this purpose usually had an upper and a lower level, with five units on each level, and it could house 10 households, with a kitchen and a toilet in the common area on each level.
} 
the incubator for a couple of days more, but actually he spent a month in the hospital. He was not discharged until my confinement was done.

Q: Did you know that Fangmiao Wu has intellectual disability immediately after he was discharged from hospital?

Mother: We had no idea. He was just like any other newborn baby, sleeping after eating and eating after sleeping, nothing unusual. When he was 9 months old, he didn't know how to hold things, and gave no response when we taught him things. We couldn't figure out what was going on, but my sister saw something wrong, so we took him to Shanghai Medical University on Xietu Road. With help, we saw two doctors, Dr. Si and Dr. Bai. After diagnosis, they said, "Your child has cerebral palsy." What a shock. Since he was 9 months old already, the only choice we had was to help him get treatment.

$\mathrm{Q}$ : In the process of treatment, have you ever thought of giving up?

Father: Never, ever did it occur to me to give up. I've always had my personal confidence. Now that Fangmiao Wu has a child after getting married, I am putting this confidence in his child.

Why? I had thought about it, and I decided that we had keep his mind; as long as the brain could work, everything would be okay. My wife suggested, "How about having another one?" I said, "No, just him.” When Fangmiao Wu was 9 months old, I asked my parents to take care of him. We lived in my mother-in-law's house when we got married, but in the end, life in the "Twenty Thousand Household" community was inconvenient. I moved everything over and told my mom, "Have a try and see if you can raise this child; feed him if he survives, but don't bother if he dies. I will not blame you for that. Do your best, but just do what you can." My mother said okay. When I brought him there, he was all bones, as if he wasn't eating enough. My mother prepared things like porridge to feed him. A 9-month-old is already able to eat staple food, and Fangmiao Wu ate the food bite after bite. My mother thought, alas, this baby was not very difficult to take care of! In this way, my aging mother brought him up to 7 years old, carrying him on her back or pushing him in a stroller. The stroller in the past had four wheels. Kids were supposed to sit inside. However, we had to heighten the side to keep him inside in case he fell out, since he still needed to be in it when he was over 6 years old, and he would stand up. It would be dangerous for him to fall off while standing in it, so that's why we heightened the side.

Q: According to the previous news reports, it was Fangmiao Wu's grandma who took him for treatment?

Mother: Yes, because we both had to work. My husband could not do it, because he worked on night shift. I couldn't either when working on morning shift, but I would take him to see the doctor when I was on noon or night shift. When I was working on my morning shift, I would ask my mother-in-law to take Fangmiao Wu to see the doctor.

Father: Yes. That's right. We were as wretched as those in desperate need, truly like them, when taking him to see the doctor.

It was a hard time for my mother as well. In the morning, my father and mother would take him out in the stroller to play, and sometimes they'd buy some snacks for 
him. The most tiresome moments were when taking him to see the doctor, because they had to carry him on their backs and take three buses.

Mother: The hospital was on Fengxian Road.

Father: We used to live in the Puxi area. We had to first take bus No. 401, get off at the Bund for bus No. 49 to the Stadium, and then change another bus to the hospital. It took them a lot of time on the way there. ${ }^{2}$ Taking him to the hospital was really hard, particularly for two old people... When my wife did not have to work, she would get up early in the morning to take him to see the doctor. We had to hold him in our arms, right? And we always expected him to get better as a human.

Two doctors from Shanghai Medical University treated him for more than 2 years, but he still walked like a horse, with his heels not leaving the ground, and forefoot and hind foot always crossing each other. The doctor tested his blood, but the results were all good. At that time Fangmiao Wu was about 4 years old. He took imported melatonin, as well as injections of imported medicines. What else could we do for him? What we were most concerned about was keeping his brain. That was the single most important thing. However, after taking injections for more than 2 years, he still could not walk, and then I began to wonder. Seeing two doctors taking blood samples from his ear, I asked what on earth was wrong with him, and the doctors said nothing was identified. What should I do about that? At that time my dad was in the Hospital Affiliated to the Second Military Medical University... for what problem? (Looking at Wu's mother)

Mother: For stroke.

Father: Right, stroke. We went there to line up in the middle of the night in order to see a specialist. I just wanted to try my luck to see what the hell was on with Fangmiao Wu. At the hospital... I heard my name called and I went in, and then a professor doctor said Fangmiao Wu had cerebral palsy. I said to him, "On what grounds do you say he has cerebral palsy? You say so without any checkup. That's it?" He said "Fine," and had Fangmiao Wu lie on the bed to examine him. After that he arranged him to have a brain CT scan.

After the test, I asked my wife to get the CT scan result the next day as I had to work. My wife took the report to the doctor, but the doctor was not there. Professor doctors like him would go somewhere else to treat patients. Anyway, my wife did not find that professor. I dialed the professor's phone number, which I got the other day, but I couldn't get through. I told my wife, "Don't worry. Just come to our factory where we have a sanitarium, pretty well equipped." Then I asked the factory doctor to read the result for us. The doctor said, "Oh whoops, looks like something's gone wrong with your son." I said, "What's gone wrong?" He said, "For your son, there's a transparent cyst on the edge of his brain."

Mother: As thin as a hair.

Father: Yes, very, very tiny. I was shocked. The doctor said, "Do not be afraid. There's a doctor named Ye at the kindergarten affiliated to our factory, who's a pediatric specialist. It is said the doctor is from Xinhua Hospital, and his teacher is

\footnotetext{
${ }^{2}$ There were no direct bus routes at that time from ChangbaiErcun, where Wu's family lived, to Fengxian Road. They had to take a number of transfers to get to the hospital.
} 
the chief doctor of pediatric brain surgery at Xinhua Hospital, remarkably capable, so I'm going to ask him to get his teacher to help me." I said, "Great."

Then, my wife and my mother took Fangmiao Wu in their arms to see the doctor. I asked the teacher if surgery was needed. He said, "No, just take three shots daily for 1 month, one in the morning, one at noon, and one in the evening, 1 month in total." I thought my son's ass was going to be riddled with needle holes, but I had no other choice but to listen to the doctor. After a month of injections, my son would also need to take medications for another month, three times a day; that is, morning, noon, and evening. The doctor said to my son, "You should be able to walk after completing the medical treatment."

He really wore his grandma down during that period of time, who piggybacked him all the time and ran here and there. When he walked, he walked like a wild horse. We walk like this, but he walked like this (imitating the way Fangmiao Wu walked unsteadily), just crossing his steps, with no landing on the ground. What should we do with that? After treatment by the doctor from Xinhua Hospital, my mom let him walk by himself at the age of seven. He just started walking like a child, moving slowly on someone's support, then he could walk slowly with his hands on the bed frame. My mother thought to herself: this little guy can even stand up! She told us when we came back, then I became more confident, and took him to more treatment. I believed that we hit luck at last. For us, money did not matter that much, as long as the child could stand up and walk. Finally, we found a good doctor. I was really thrilled.

You see, money was... Oh never mind, and the moment my wife received her wages, all was spent on him; the moment I received my wages, all was spent on him. The two of us only spent, say, 5 yuan in total every month.

Mother: In the past our wages were very low, only a little more than 40 yuan.

Father: I started working in 1982, and my wife worked the hardest in the mill, but even so, she could only make about 200 yuan a month. You do the math. At that time, I did not make much money in the factory, and her mill at that time was running relatively well, but still 200 yuan was almost nothing. Back then all the money we got would be instantly spent on him. My mom and our sisters also helped with their money, including their monthly bonuses. In this way, total expenses, including medical fees spent on seeing private doctors and state hospital doctors, may well amount to at least over one hundred thousand yuan. One hundred thousand yuan at that time could not be compared with the same amount today.

The two of us were surely feeding off our parents. We couldn't help it, because we had no other choice. Our only expectation was for him to get better. Finally, finally, the dream came true, ha ha, finally it came true!

After Fangmiao Wu could walk, I took him to the lawn. There was a lot of grass in the garden of our community, like a lawn. He liked to play soccer when he was a child, so I bought a ball and put it in the center of the lawn. The grass was tall, so it wouldn't hurt even if he fell on it. He kicked and missed, kicked and missed. You see, his knees are not the same as those of others, and his right knee is a little bit thicker, which is the result of having fallen down too much. Again, we had no other choice. What else could we do? We also took him to the lawn of Yangpu Park, where 
he would play and fall on the turf. Hey, gradually, he learned to kick. He moved very slowly, in a shaky manner, but it was good as long as he could keep his balance. Looking back, I think such forced exercises were very good for him.

\section{Our Miao Miao Is a Smart Boy}

Q: In addition to teaching him to play soccer, what else did you use for the development of his intelligence?

Father: Well, I took him out. First of all, I would take him to Xijiao Zoo where he would see animals like tigers, and I would tell him the names of the animals. Second, I would take him to see the big ships on the Bund, and tell him what these ships were like. There was a ferry dock nearby, so we would take him for ferry rides, and tell him here was Pudong and there was Puxi. I was working in the Machine Tools Works at that time, and there was a warship anchored at Wusongkou, just over there from the end of our plant's banner. I would tell him, "Daddy is going to take you over to have a look," and take him to check what the warship was like. Wherever I went, I always took him with me and talked with him about what he saw along the way. I wanted him to remember what he saw. That was before he began his schooling. Why did I talk about these things at that time? I tried my best to make him understand. I just wanted him to know what it was the moment he saw something. Generally, he could understand after I told him a couple of times, pretty smart. He could not run very far, and of course he could not run faster than those who had healthy limbs. He was inclined to play by himself at home, and sometimes did some writing.

Q: In addition to playing soccer, what else did he like to play when he was young?

Father: Just like other kids, he would play this or that for a while, nothing special, but basketball was his favorite. He also liked to bounce the basketball.

Mother: It was not easy for him to walk. Our kid had no particular hobbies. Why? Because he started to walk rather late and could not even walk very far at that age.

Wu: At that time my family lived on the first floor, and I just played outside.

Father: He could not walk far. When we saw other children playing outside, we would ask them to play with Fangmiao Wu for a while. At that time, he had just learned to walk. Many of our neighbors watched him grow up. They would tell their children not to touch Fangmiao $\mathrm{Wu}$, as he was a kid brought up with money (laughing)... "This kid was raised with money," really funny. Then the other children became afraid of playing with him, worried that they might hurt him. Yet Fangmiao $\mathrm{Wu}$ loved to play with others. He felt bored staying at home all alone and preferred to go out and play with others. After I came back home, his grandparents would take him out and let him eat whatever he wanted to eat. It didn't matter much to be poor, as long as the child was happy, healthy, and smart. The rest is not important.

Wu: I liked to play with girls and didn't like playing with boys. Boys would bully me, but girls wouldn't.

Q: What games did you play with them? Hide and seek?

$\mathrm{Wu}$ : Playing cards and soccer.

Mother: Basketball, soccer. When he just started schooling, he could not even walk steadily. 
Father: The school was afraid of accepting such a student who could barely keep his balance, and teachers were worried that something might happen to him, right? They rejected Fangmiao Wu at registration, saying that he could not study there. My mother and I were not convinced, so I argued, "Why can't he study just because you say so? You must give him a place to study." My mom went to the Education Bureau of Yangpu District. Fools cannot go to school-my mom knew it as well, but the problem was: since Fangmiao Wu's brain was working perfectly, how come he was denied schooling? Now they saw our child walk a bit ruggedly for sure, but his brain was good. Then the Education Bureau gave the school a call and let him go there for education.

We went to the school to register him again, but when we got there, a teacher again said that Fangmiao Wu could not register. Then another teacher ran out and asked, "Which child could not register?" After sizing up Fangmiao Wu, he said that he could register, as the Education Bureau of Yangpu District said so. Well, finally he got registered. I believe Fangmiao Wu was quite smart. He had never gone to day care or kindergarten, and he didn't even know what a test was. He had no idea about it, right? Yet step by step, he would learn, and I think our child would be like this. Now that his brain was saved, he was a smart kid, too, right?

Q: Which school did you go to?

Wu: I started at a special school. At school, we just studied some simple Chinese and arithmetic. Pinyin was also offered there. The level of learning was not the same as schools for normal kids.

Father: To put it this way, for the textbook of first grade, they would just teach half of it at special school. The progress was very, very slow.

Wu: Even less than half. The progress was truly slow.

Q: If Fangmiao Wu believed it was slow, it meant he had mastered the knowledge. (All laughing) What were other students like?

Wu: I was physically disabled, while they were intellectually disabled. That's why I believed I did not belong there, but schools for normal kids wouldn't accept me, afraid that I might cause trouble for them.

Father: Other kids indeed had low IQ. You went there simply because there was no other way, and you had to study at some place. Fangmiao $\mathrm{Wu}$ could not walk well, so he couldn't go to a school too far away, but his brain was good. The school he went to was Changbai Yicun Elementary School.

Q: As a student in the special class at the school, did he learn together with normal kids?

$\mathrm{Wu}$ : There were three classes for normal kids, and we were placed in the same building with them, for 5 years. We had PE class together with the normal kids, and usually we wouldn't fight if we were put together. Even if there was a fight, it was a very small probability. Anyway, I did not see any, and I was very cheerful. On the other hand, when someone saw me like this, certainly there would be something on his mind, and they choose to avoid me. I would not provoke others.

Q: Then how come you went to Yangfan School later on?

Wu: Our special school was run by the Education Bureau of Yangpu District, in a very small school building, so if there were too many students there, you would be 
assigned to a general school where there were three special classes. I was assigned to one special class at Changbai Yicun Elementary School. We merged into the main campus of Yangfan School located in Yanji Wucun after we had finished the fifth grade.

Q: Your classmates and you stayed in the same class from elementary school to junior high school, right? Did you have any good friends? Did you have any outings in spring or fall?

$\mathrm{Wu}$ : Yes. As for good friends... how to put it, generally speaking, there were a few on good terms with me. Every year we had outings in spring and fall just like normal students; we had activities in both spring and fall, and usually we went to the park, like safari zoo, and we went to some places far away, like the American Dream Park in Nanhui.

Q: Did you go to school by yourself, or did your parents take you there?

Wu: I was taken to school from the beginning of elementary school till Grade 5. Sometimes by my granny, sometimes by my mom. I came back home for lunch at noon. For most people, it took about a quarter of an hour, but it would take me 20-30 min to stagger back.

Father: Yes, he came back for lunch at noon, and if he had class in the afternoon, we would take him back. So we walked back and forth.

Mother: There was quite a distance to the school at that time. The school was located in Yanji Wucun on Dunhua Road, but we lived in Changbai Ercun.

Q: When did you learn to dress yourself and brush your teeth? Could you do housework?

$\mathrm{Wu}$ : In my teens. I remember I learned to dress myself in my teens. I could do some simple housework, like cooking and making snacks.

Mother: He could wash dishes, and at school, they were taught how to cook and how to make snacks.

Wu: Simple tasks like using the sewing machine, ironing clothes, I could handle.

Q: Oh, how long had Yanfan School been in operation?

$\mathrm{Wu}$ : It had been in operation for more than 20 years, and it had been there since I was born, but it was relocated three times. It was a one-stop school, with nine grades in total. After finishing all grades, you could continue at a vocational school if you wanted to, where you were supposed to learn with normal students. If you didn't want to go to the vocational school, you had to find your own way to support yourself. In addition to the hands-on classes of labor skills in the school, language, arithmetic, and computer courses were also offered.

Father: When he just started schooling, a pen to him was heavy as hell. It's not heavy literally, but he used too much effort in using it. When he was writing, he would like to bite his hand to stop it from shaking. Oh, my, there was even a cyst ${ }^{3}$ on his hand. Actually, he used so much force that even the pencil lead would be broken, so I had to sharpen it for him again. When writing exhausted him, he would hold on to it with his sleeve between his teeth, so slowly and slowly he learned to write. It saddened me when I watched this poor guy writing like that, but I had to harden my

\footnotetext{
${ }^{3}$ Fangmiao Wu wrote with so much force that cysts formed on his fingers.
} 
heart and let him complete his homework. He had to learn to write, anyway. Later on, it was just fine.

Mother: That was in grade one.

Q: After you came back home from school, did you need your parents to help you with your homework? Dad said he had to watch over your writing.

Wu: (Laughing) Tutoring was not needed.

Father: After he learned how to write, I would let him do his own homework. We had free time only at night, because we had work to do. After cooking and preparing, granny would call him, "Miao Miao, come for dinner." Then we would sit down to eat. After dinner, she would ask him, "What else do you need to do?" Generally, nothing, after homework was done.

Mother: They had very little homework, and basically it was done in the classroom. When he came back, there were only some words to be written from memory. Copying the words the first day, and writing out of memory the second day. That's where we came in. Nothing else except that. At that time, he had never attended any elementary school, never learned how to write, and we had no idea how to teach him to write, so he could only learn by himself.

$\mathrm{Q}$ : Were there any differences between you and your wife's policy about Fangmiao Wu's education?

Mother: (Laughing) We did not have any education policy; Fangmiao Wu just learned everything by himself, his own way.

$\mathrm{Q}$ : Were the classes offered on the basis of intelligence levels? What was Fangmiao Wu's favorite course?

Wu: Yes. Everyone's intelligence level was different, but we were mixed in one class, and classes were divided according to age. I loved PE the best.

Q: Oh, really. Speaking of sports, when did Fangmiao Wu start playing basketball?

Mother: When he started elementary school. In fact, when he was a child, he showed interest in basketball and soccer, although he would stumble as he walked at that time.

Father: When he played soccer, he kicked and missed, kicked and missed, and his pants got ripped when he walked and stumbled, so we bought some flower-pattern patches and stuck them on, always on the knees of his pants. No one would care much about the flower patterns, since he was only a kid.

I would be with him all along whenever he went to play basketball or soccer, even when he played basketball at the Machine Tool Works. He loved playing basketball, so we went to my factory. I got two co-workers to play with him, not a bad idea. When he first started school, we did not allow him to have PE class. Why? He was pretty frightening like that, so the teacher did not let him have PE class, either. However, this kid loved basketball so much that he always bounced the ball at one side when others had the class. The PE teacher would tell him, "Take your time bouncing the ball, just don't run." I could not watch over him because I was working.

Q: Between soccer and basketball, why did Fangmiao Wu choose the latter?

$\mathrm{Wu}$ : Because it was easier for me. Basketball shooting only requires the use of hands. You don't need to use your feet to kick. I began to like it when I was in Grade one or two. For basketball training, well, I just stayed after school for it. There were 
PE teachers taking care of the training. From Monday through Thursday, he would stay and train us for an hour every day. On our team, all had good hands and feet but me, but their minds didn't work very well. I was not very good at using my hands, but had no problem with my mind, so I played guard. Besides playing basketball, I also played soccer, as a goalkeeper. I couldn't run well, but I could be the goalkeeper. My classmates were just the opposite. They had no difficulty running, but had a hard time kicking.

Father: Our Miao Miao was quite smart. His teachers were very nice to him, and took good care of him. Even now we are still in touch, with that music teacher who is still teaching at the school.

Wu: I liked my class teacher, and he's also our music teacher. The PE teacher was also not bad.

Q: Was your class teacher the one at Changbai Yicun or at Yangfan School?

Wu: He was the class teacher after I was transferred to Yangfan, Mr. Bin Gu, a music teacher, and he was the teacher whom I contacted a lot. From elementary school till graduation from junior high school, he was my favorite teacher, and he was kind of like a friend. Some children did not like to speak, but I like talking a lot, and I liked to watch national events, news, and I like to communicate with people about these. Sometimes when I encountered difficulties, like difficulties in life, whatever kind of difficulties, I would like to go to him for a chat, then he would share his ideas with me. When I was in Changbai Yicun Elementary School, I liked my Chinese language teacher, who was also my class teacher. As an active boy in class, unlike those reticent students who did not like to speak, I was eager to communicate with teachers, and teachers also liked to communicate with me.

As for the PE teacher, I began to know him in my junior high school. We had PE class all the way from elementary school to junior high school. In the beginning my body was not ready for PE, so I did not start my PE until I was in junior high school. In the beginning, as my father said, I was put aside when they had PE, and two classmates were dispatched to take care of me, and we would chat and play together. Although their minds were not good, their hands and feet were good, so physically speaking, they took good care of me. As I was more mentally active, I would help them with schoolwork. One good turn deserves another, right? For example, if they could not solve their math problems, I would explain very, very slowly to them, step by step. I couldn't have been slower. I did it very slowly so that they could understand.

Mother: His PE teacher has received media interviews and appeared on TV as well.

Wu: Yes, they interviewed him about me. His name is Wei Wu. He appeared on TV after I became famous.

Father: His PE teacher took good care of him. I can't remember when he said he would go to play basketball games in Harbin. When I heard this, I thought: "What? You are going to play games?" Later on came the World Special Olympics, and someone recruited him [shooting promos], oh my, a lot of things. I told him, "Handle and settle everything on your own, just the way you like."

One day Fangmiao Wu said to me, "Daddy, I'm going out for a run." I asked, "How could you run?" He said he would just go jogging. We lived in Changbai Ercun, 
where you could jog around slowly in the community, so I thought it was okay for him to jog. If he could not even walk stably, how could he have PE class? Later on, after he could walk more steadily, we would allow him to do what he liked: "You can do whatever you like, but you are old enough to know how to protect yourself, and you can't always stumble your way. It wouldn't matter if you just bounced the ball. Just enjoy yourself."

\section{The "Hiding" Special Olympics Ambassador}

Q: When did you first hear of Special Olympics?

Wu: I heard about it earlier than my parents, because we had our Special Olympics at school. I learned about it maybe in the sixth grade, and I wanted to participate the first time I heard of it, because I had a goal of participating in sports games. Our school participated in the 2005 Shanghai Special Olympics, and we won the championship. We were chosen to represent Shanghai in the 2006 National Special Olympics, just one level up after another.

Father: Fangmiao Wu also shot a promotional film, before the foreigners came to plan the Special Olympics opening ceremony.

$\mathrm{Wu}$ : It was a public service promo, and it was the product of a Sino-US cooperation, by an American director and a Chinese director. Although the shooting was very tiresome, I had a great time, because I could let people know about the people with ID.

Father: The advertising agency came to their school, for a visit... but he was timid, so the advertising company asked the PE teacher to get him to the office and asked him if there were any barriers in our home. Fangmiao Wu said no. The agent then asked if it would be okay to visit our home. He said yes very readily, and gave the phone number to the agent. So the advertising agency came to our home, shooting film and asking questions. This ad was shot before the opening ceremony of Special Olympics as public promo. At that time, all bus stops were displaying his promo, in which there was a motto written on his hand: Come on, Kids!

Q: Why were you chosen for the promo?

Wu: (Laughing) I was a little bit more active, and my mind was better than the other students; when they came to select the actor, they talked to every kid. My performance was more impressive, so I was chosen.

Father: After the promo, he was invited to Beijing to attend a press conference for Chinese and foreign journalists, and Ming Yao went there, too.

Wu: There were a lot of celebrities.

Father: Ming Yao gave him a basketball as a gift, which he held dearly as a priceless treasure. (Picking the basketball up off the living room display shelf and showing it.) You see, there is an autograph on it (see Fig. 1).

Wu: I never played with it after taking it back, and it's too soft, anyway.

Father: There are a lot of photos here, Ming Yao, Xiang Liu, and Hong Kong celebrity David Wu, all autographed for him. And Yu Lu as well. This is the Special Olympics opening ceremony; this is "A Date with Yu Lu" after the Special Olympics; this is the autograph from the Hong Kong celebrity David Wu; this is his wedding photo, and this is his wife and child... (showing photos). 


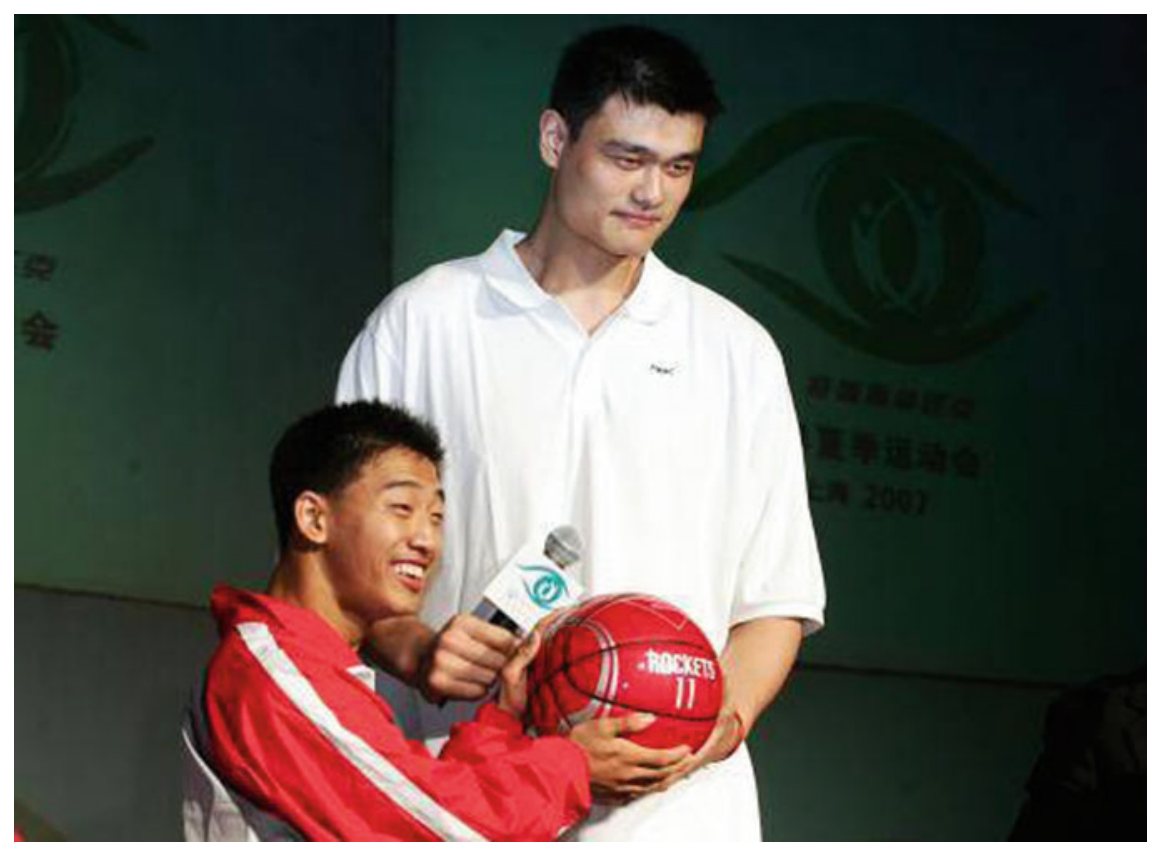

Fig. 1 Fangmiao Wu and NBA player, Ming Yao, 2006

Q: Wow, really nice. Just now we talked about going to Beijing to attend the press conference. Any details?

Father: Ah, there were the foreign journalists for the international press conference as well... could you recall any? (To Fangmiao Wu) Media included China Youth Daily and... really too many, all around him, interviewing him. At that time, we had not moved over here yet, we were still living on Jiamusi Road, Yangpu District. One group after another came to interview us. Shanghai TV came most frequently, and Dragon TV too. Shanghai TV formed a special team, specifically trained to follow Fangmiao $\mathrm{Wu}$, and HKSTV was following him, too. HKSTV was the first media to follow him, as early as 2006 when he went to Harbin [to participate in the National Special Olympics].

Wu: As I went to Harbin on the 28th, just after the press conference (for the promotional film) on the 21st, HKSTV began to follow me. At that time the leaders from the Shanghai Federation of Disabled People met with us athletes, a delegation of 54 people, in Harbin. When I got off the plane, our leader told the TV reporters that this was Fangmiao Wu.

Father: With cameras in position, shooting began as soon as Fangmiao Wu turned back. They followed him to Harbin, and then followed him back.

Wu: After the Games they also sent reporters over for a home interview.

Questions: Of all the athletes, why did they single you out to follow? 
Wu: Because I was the ambassador. I was chosen as the Special Olympics Ambassador after the promo was released in July 2006.

$\mathrm{Q}$ : Oh, how were you chosen to attend the opening ceremony of the 2007 Special Olympics?

Wu: When they came to pick performers for the opening ceremony of the 2007 Special Olympics, our school first recommended us, who had been to the Games, to those directors, but at that time I was a little afraid. So I went hiding in the washroom before it was my turn. Finally, I was pulled out by my classmates, and then they saw me.

Father: After the promo, whenever he went out jogging, people would know his name. When the Americans came to pick performers for Special Olympics, he was chosen. That day the Americans came to their school and picked Fangmiao Wu, and when they watched the promo at night, they said, "Oh, this guy is Fangmiao Wu, nicely shot." After a week, a phone call came for him, inviting him on a business trip. I began to wonder where such a young kid could go for a business trip, but then realized there was a team to go with him. We gave him permission to travel to Shaolin Temple in Henan, to climb on top of a "great wall," which was a wall made up of students from the martial arts school who were connected with each other through rods. I thought it was very good, and when this kid came back telling me this, I asked him if he had confidence, he said yes.

To walk well down the road, he had to have confidence first. Oh my, too many reporters came to my home for interviews at that time. Oh, he was really involved in so many activities back then, and as parents, we had no choice but to accompany him. Fangmiao Wu asked me, "Dad, what requests do you have?" I said I had no requests but a piece of proof, which I could use to ask for leave from work. Then they gave me a piece of proof, with a seal mark stamped on it. I took it to my factory and I was good to go on leave. As long as my son needed company I stayed with him, anytime, anywhere. That's the way it was. I thought that it was important to my kid, and Special Olympics was a very good opportunity for him to develop his abilities.

Q: I see. At the opening ceremony of Special Olympics, what was "the Great Wall" in particular?

Wu: It was a wall built with people. I have a film here, so let me show you.

Father: (Taking out a document portfolio) Here. Everything in this portfolio belongs to Fangmiao $\mathrm{Wu}$, including the previous interview records and certificates he received. I put everything of his in a safe place. This is Fangmiao Wu visiting the local zoo when he went to Harbin... Oh, Fangmiao Wu has a good collection of stuff.

(Playing the video of opening ceremony of 2007 Special Olympics.)

Father: They were training really hard at that time.

$\mathrm{Wu}$ : There were four of us performing, two men and two women, in Team A and Team B, or a main team and a substitute team. It was made very clear that only one man and one woman would be finally up there on the stage at the opening ceremony, and the choice would be made based on performance during training. Therefore, I trained extremely hard. 
Father: Once Shanghai TV came to interview him, and he was so tired after he went back that he fell off the "wall" in a training session. He got sunstroke, no joke, because it was outdoors. Oh, that was really funny, so we had to take him back and he rested for a couple of days before going back.

Q: You made it to the opening ceremony of Special Olympics with your own effort. Did your parents come to watch the ceremony? Was there anything particularly impressive while watching, uncle and auntie?

Wu: They didn't go to the one in Harbin, but they did go to the Shanghai Special Olympics.

Father: My impression... we went there to cheer him on, looking down from the second floor, to cheer Fangmiao Wu. When we watched the training videos, we were sure everything would go well, but when it was your turn, we felt a little panicked, because so many people were watching you. That made us feel a little panicked. The performance in the video seemed pretty good, but when you performed live, there were some small errors.

Wu: I was a little bit nervous.

Father: I went to the opening ceremony, but I did not watch the games or the training. I had to work, and there was no way to get away from it. I didn't go until I got the ticket.

Wu: I went to the training myself.

Father: Yes, I asked him to go there himself, and there was a car to take him back. I thought if you could go and come back by yourself, then I wouldn't need to worry any more.

Q: Did Mom and Granny go to watch his games?

Father: Granny didn't go, but Mom did, taking transit with a transportation card. It was the all-purpose card given by the Organizing Committee for Special Olympics. They could use it when going to the games. Oh, speaking of this all-purpose card, its balance ran out after only a few days, very fast.

Wu: There was a lot of money deposited on it, 1,500 yuan actually.

Father: After watching the games, they would go to his auntie's house in Meilong. Round-trip taxi rides cost a lot of money. And then they would take a taxi to People's Square, so the money on the card went very fast. When I finally settled the account, I had to give extra money to them, but I was willing to pay out of my own pocket, as long as Fangmiao Wu was happy and performed well.

The American director also took you to the park, and you tried something that went up and down. What is it called? (Looking at Fangmiao $\mathrm{Wu}$ )

$\mathrm{Wu}$ : After the opening ceremony, they were going back. On the last day before they went back, they took me to the park. I played turbo drop there, just near Jinjiang Amusement Park.

Q: Besides being the ambassador, did Fangmiao Wu do any other job at Special Olympics?

Wu: No. In 2007 I only attended the opening ceremony, but did not play in the games.

Q: Were the basketball games at Special Olympics different from the general type of basketball games? In addition to basketball, what other sports do you like? 
Wu: There were differences. Our basketball games were divided into two categories, one for groups, the other for individuals. For groups it was five vs. five, and the time was shorter. For general games, a quarter is $12 \mathrm{~min}$, but we had $24 \mathrm{~min}$ in total split into two halves. Besides basketball, I also like soccer. Actually, I like all kinds of sports.

Father: After he came back, when Special Olympics were over... when was that? (Looking at Fangmiao Wu)

Wu: October 2, 2007.

Father: After coming back, Shanghai TV called us, asking him to record a program. I told him to go by himself and raise requests, if any, beforehand. Although as a parent, I had many of my own ideas, I should not intervene. Let the kid go to put forward his own requests.

\section{Three Generations with a Promising Future}

Q: Were there any changes to your family after Special Olympics?

Father: As for changes, we were elected "Family of... something" after Special Olympics... and appeared on Dragon TV, and the trophy is still there. Let me show you. It's pretty heavy.

(Showing the trophy off the showcase.)

It says "2007 Figure of True Love," once there was a program on this, and Fangmiao Wu was in it. He was interviewed by Dragon TV.

Q: Have you found any change in Fangmiao Wu? For example, communication skills.

Father: As far as communication skills are concerned, I have always told him, you'd better communicate more with the normal kids and have fun together. But if there are more than three normal kids staying together, do not bother them. Why? I was concerned about his safety, so do not disturb a group with more than three kids in it. Communicate as much as you can within your own group, but avoid going out of your group if possible and do not chat beyond your limits. If something really happens, it won't be easy to hold someone accountable for that. When I said this to him, he commented, "Daddy I know." I also told him that it would be fine to communicate with people in your own circle, but you'd better not do so with people outside your circle, because you might have no idea if they are good people or bad people.

As for athletic skills, now that he has a child, and he also needs to work, his athletic skills have regressed a lot compared with before, honestly.

After the International Special Olympics, he thought there was nothing for him to do any more, so he needed to look for a job, as he was already 18 years old. We began to talk with him about a job, and he had to find a job to make a living. There was no point staying at home and "living off government money," and how could he stay at home every day, doing nothing at all?

There were twists and turns in his job hunt, and Fangmiao Wu could not find a proper job in Yangpu. Just at that time we were to be relocated to a new home. My son said, "Dad, let's move to Pudong." I asked him if he was sure of the idea, and he said yes. So we packed everything and moved here. Now the head of this 
household is Fangmiao Wu. Life couldn't have been more enjoyable for him. After all decorations were finished, we moved in. He began to look for a job again. My opinion is that no matter how much he could earn, it would be okay as long as the workload was light, he was happy about it, and there was a retirement pension plan. I need to be realistic about what my kid could handle, so I said to him, it would be okay as long as it can give you a pension plan.

$\mathrm{Wu}$ : It depends on ability, that is, I could make as much money as my ability allows me.

Father: You have to measure your ability. Frankly speaking, after his mother and I retired, I have continued to work very hard, and my wife has also been working as a traffic coordinator, so we both are still working. After our daughter-in-law had a baby, she takes care of the baby full time, so she does not work. But it takes money to feed a baby. My mother has a medical insurance and retirement pension, my wife also has a job, plus my salary, so we definitely can provide financial assistance to Fangmiao Wu's family of three. The most important thing is we live happily together. We are happy, with the whole family's attention focusing on his daughter. We do everything for our little baby, and she is also the youngest generation of this family.

(At this moment the child ran out, and everyone teased her.)

Q: Where is Fangmiao Wu working now?

Mother: Sunshine Workshop.

Wu: We sort out the soap instruction sheets here, taking the sheets out one by one and inserting them into soap boxes. I think this job is very easy for me. On the one hand, I can subsidize the family; on the other hand, I have time to take care of my family. We only have one morning shift and one afternoon shift. Generally speaking, morning hours are 9 to 11 a.m., and afternoon hours are 2 to 4 p.m. I can come back home at noon for lunch, since the workshop is just across the street. I can go back home to take care of my child at noon. It's very good.

Q: Are there any other Sunshine Workshops in Shanghai?

Wu: There's one in every community.

Father: There is a Sunshine Workshop in every community, and the only difference is that some offer better benefits while some do not. In a word, more money or less money.

Wu: No, one is "Sunshine Home" and the other is "Sunshine Workshop." These two are different, and the benefits they offer are also not the same. Sunshine Home does not pay for employees' insurance or pension, while Sunshine Workshop does. Sunshine Home is not the same as ours, and I don't know what they do there.

Father: At Sunshine Home, a bunch of people with "low IQs" are put together, and the community takes care of them for you. But for people like Fangmiao Wu, they go to Sunshine Workshop, a place of work. He was not so deft when he just went there, so day by day they told him how to do it again and again, and when they thought he was capable of working by himself, they just let him do it. Now he can work.

Wu: The money I make at Sunshine Workshop is extra money on top of subsistence allowances... (my work is) counting, that is, counting the number of instruction sheets, counting how many of them I sort out every day. 
Father: That is his work results. For example, if he wants to make 50 yuan today, he has to turn in stuff worth 50 yuan, and if it is not enough, the money will be deducted.

Wu: No deductions actually. We make less than 3,000 yuan in total, but after deduction of the pension, three insurances and the housing fund, I only receive less than 1,500 net.

Q: After Special Olympics in 2007, did the Shanghai government give you any additional subsidies?

Wu: No. After Special Olympics, I rested for a year.

Father: Did you have summer vacation in your school?

Wu: On hot days, we couldn't go to school if it was above $35{ }^{\circ} \mathrm{C}$. After Special Olympics, we were relocated here.

Father: Before coming here, we lived in Changbai Ercun, Yangpu District, in a decrepit house.

Q: How are you getting along with your colleagues now? Any good friends?

$\mathrm{Wu}$ : I get along with my colleagues very well, and I have good friends. Sometimes a phone call between us every day, to discuss where to meet and go to work together.

Father: Waiting for him... those two go to work together. They work very hard, waking up at $6: 30$ or 5:30 in the morning. His daughter would make noises around that time so he cannot sleep any longer.

Q: Do you have to take care of your child late into night after you come back from work? For example, to dress her?

Father: Even if Fangmiao Wu really wants to hold the baby, I would not allow him to do so, because his hands and feet are not reliable. I'm worried that he would drop her. When I don't have to work, most of the time it's me who takes care of her. If the weather is good, I would take her out for a walk in the park in our neighborhood. I like to let her walk more.

Q: When was the first time that Fangmiao Wu received his salary? What did he do with the money?

$\mathrm{Wu}$ : Let me tell you, my first pot of gold is this (pointing to atrophy). I got 10,000 yuan.

Father: This one?

$\mathrm{Wu}$ : Yes, this trophy, and I was given this much money after the award ceremony. The first thing for me was to buy a cellphone with the money, and then I deposited the rest in the bank.

Q: What did you do on weekends before you had the baby? Still play basketball?

Wu: I'd watch TV. I stopped playing basketball after we moved here. Previously when we lived in Puxi, I did play. My age is going up, but my stamina's going down. Normally we would go to my cousin's place. My aunt is very nice.

$\mathrm{Q}$ : When it comes to family, when did you and your wife start the relationship?

Wu: Oh, it started in 2015.

Wife: No, obviously it was in 2014, the end of March 2014.

Wu: Oh yes. We met online, as I usually played games, mainly QQ games. However, I didn't meet her while playing games. We met on Momo instead. I knew her at the end of March, and one day when we were chatting, I invited her to come to 
Shanghai as my birthday was on May 16th. She was from Hunan by origin, so she came, and has stayed at my place ever since. She doesn't have a job, so she just stays at home. After we got married, we had our baby on July 30, 2015. At the childbirth, we were a little worried that there might have been genetic influence.

Father: Nothing to worry about, as you have your family behind you.

$\mathrm{Wu}$ : I was worried that my conditions would be passed down to the baby. I asked an expert later, according to whom cerebral palsy would not be passed to the next generation, and then I was assured.

Q: Does your wife think that your conditions cause some inconvenience in life?

Wu (Looking at his wife): Do you think so?

Father (Waving to daughter-in-law): Come here, come and share something with the reporter. I can tell you that my daughter-in-law is now very happy in our home.

Wife (Came over and sat down): Inconveniences? I don't think so, and everything's good.

Q: What did you do before you came here from your hometown?

Wife: I did not work in my hometown. I stayed out of town all alone. I wandered everywhere, used to work in Zhongshan, Shenzhen, Zhuhai, and Guangzhou, doing everything.

Wu: She does cooking and embroidery and almost everything.

Wife: After I met him in Shanghai, I've stayed here, but not working. Oh no, I worked as a subway security inspector for a month.

$\mathrm{Wu}$ : We helped her find a job as subway security inspector, but she quit after she got pregnant.

Wife: That was just a few months after I came here. I started working there between September and October 2014, as a security inspector for Metro Line 12. After a month, I found I was pregnant, so I stopped working. I got pregnant in October, and by the end of October I didn't work any longer. After getting pregnant, I just did grocery shopping and cooking every day at home.

Q: When you decided to get married, what in Fangmiao Wu attracted you?

Wife: After all, I am 2 years older than him, and at that time I thought it was time for me to get married. Also, my parents-in-law were very nice to me, so I thought it did not matter much how he looked like; anyway, about life, I am not so picky. I thought he was a very nice guy, so I agreed to get married. We got the marriage certificate first, and after half a month I found I was pregnant (see Fig. 2).

Mother: The child is super smart now, only 15 months old.

Q: Yes. What is her name?

Wife: Yuhan $\mathrm{Wu}$, Yu meaning "rain," and the character "Han" having a grass radical in it.

Q: I think she will play basketball later. She looks very agile. Do you have any expectations in life now?

Wu: Just nurturing the child well. (Others echoed) We two will do our best to raise her.

Father: My ears are not good, so for this interview I have specifically put on a hearing aid.

Q: What's wrong with your ears? 


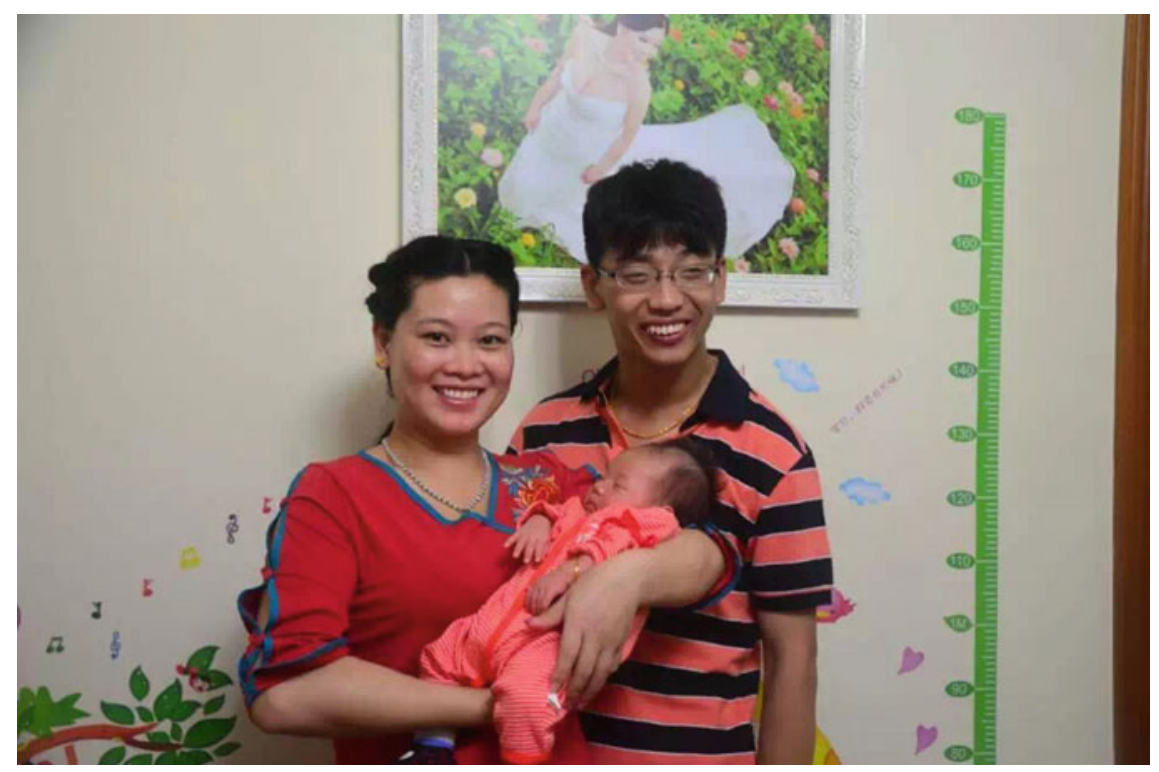

Fig. 2 Fangmiao Wu and his family, 2015

Father: I got otitis media in my childhood, had three major surgeries since I was six. The inside of my ears has festered away, causing perforation in both ears, and nothing can be done about it. Just then, our factory was running a disability check, so I stuck my forehead out, ${ }^{4}$ and I was lucky. I showed to them the doctor's diagnosis on my medical record from when I was a 6-year-old. They had a review and identified me as level 2 disabled.

I retired after I turned 50 years old. When I just retired, my monthly income was 1,700 yuan. Since then, my retirement pension has kept increasing all the time with those eligible, and now I am also considered as a member of the retired. I am working part time now in the field of property management, and it doesn't matter if the money is not so good, as long as our family can be better. Taking into account the whole family, I wouldn't mind if life was harder for me. Most importantly, Miao Miao and his wife can have enough to support themselves. As for their child, we'll do everything for her. That's why I go to work early and come back late. I get up at five o'clock, but will not come home until 10:30 p.m.

Q: Are you still working like this now? Why do you work for such a long time?

Father: Yes, right now. Currently, I work every other day as a security guard in a different community. I do not work on night shifts, only on middle shifts, but there is no subsidy for middle shifts.

$\mathrm{Wu}$ : That is, one early shift and one middle shift, $16 \mathrm{~h}$ in total, $8 \mathrm{~h}$ per shift.

Father: Usually people work for $8 \mathrm{~h}$ a day. I'm now working one day for $16 \mathrm{~h}$ and taking a break the next day, so it's still like I work $8 \mathrm{~h}$ per day. Little money, hard

\footnotetext{
${ }^{4}$ Have one's forehead stick out: colloquialism in Shanghainese, meaning "to try one's luck."
} 
work, but I don't mind as long as the family's happy and I can support them with some money, or you tell me what I could do otherwise. You agree with me, right? It is most important to be happy. Fangmiao Wu had a poor childhood, but now he's doing well.

I think most of the credit goes to his grandma. Because most of the time it was her who took Fangmiao Wu to the doctors, carrying him on her back, taking Bus 401. Before that we took the "caravan"5 in front of our factory, then transferred to Bus 401 to the Bund, then changed to Bus 49 . Oh, the bus was really packed like sardines, with so many people commuting at rush hour. We both had to work. I said to my mom, "Mom, all credit to you, I know it's really hard." I had thought that if my child was born healthy, I would nurture him well, and when he grew up I would send him to serve in the army, which seemed to be very good. However, my dream was shattered after Fangmiao Wu was born. Such an idea became unrealistic.

Wu: We still have the next generation.

Oh, it's hard to tell for this generation. Our granddaughter is super smart, and all I'm thinking now is making money for her. We'd like to send her to get an education when she's 2 years old, starting a collective life early. That's what's on my mind. Otherwise if you suddenly put her into a nursery or kindergarten when it's time for her to go there, it would be too hard for her. After 3 or 4 days, she would be crying, which would make my heart break, and I would take her back. That would definitely make my heart break. Therefore, to take advantage of the moment when she doesn't know much, we have to throw her into a collective life, so that she can adapt to that way of life before she knows it.

Our child is very smart, as I have been watching her. There are a lot of children upstairs and downstairs, but whoever sees her says that the child is smart, incredibly smart, even giving her a nickname "Smartie." Why? When someone calls my granddaughter, she would always give them a serious face, no smile at all. When they offer her something to eat, she would not touch it at all. But when at home, if asked, "Where are Grandpa's socks and slippers?" she will know (and get them for me) without being told twice. Oh, this kid understands so many things. The child next door is 2 months younger than ours.

Wu: 20 days younger.

Father: That one is not as smart. I have brought up four children: my nephew, my niece, Fangmiao Wu, and my granddaughter. My granddaughter is the "last empress." The most difficult to take care of was Fangmiao Wu; the second most difficult to take care of was my brother's child; the best was the eldest, that's my nephew; and then the second best down the line is my granddaughter. In our family, they have kept saying that this little granddaughter is growing up in her grandpa's arms. I truly love her. I already said to Fangmiao Wu, "You have to put up with me and understand your old man even if I am not being sensible sometimes. I am working very hard and

\footnotetext{
${ }^{5}$ Caravan: an articulated bus, usually twice as long as an ordinary bus, with a black rubber connection between its two cars, which bends when the bus turns. In order to accommodate more passengers, most of the seats on the articulated car are removed. Shanghainese usually call it a "caravan." In 2004, the last articulated bus on bus route 124 stopped service.
} 
doing a lot of things, so if there are some chores at home, just handle them yourselves and don't expect me to do everything for you, right?" At the same time, I promise that I will take care of this child until I die, and I have to do so because my son's hands and feet are not good enough to hold her. I am a man of my word. What can we do with the money we have made? Why am I working again instead of resting at home after retirement? I'm doing everything for the next generation, right? You have to create good conditions for the next generation to make them happy. Oh, I cannot afford a house though. I won't be able to make so much money.

$\mathrm{Wu}$ : The poor change their life through the government's relocation program.

Father: No matter how you change, the problem is: can you really change your life? If you can, great; but if you can't, there is nothing else to say. The house we are living in is not bad, three bedrooms and one living room, although we tried to restructure it into two bedrooms and two living rooms for him. We didn't expect him to get married so early. Then so be it, and we aborted the plan. Let's not worry about other things as long as we are happy. We are happy to be Grandpa and Grandma, and happy to become old. Nothing is more important than happiness.

Q: Finally, I have a few other questions, one of which is: In what ways do you think Special Olympics can be better?

Wu: I think... in fact, I think people with intellectual disabilities should be given more opportunities to participate.

Q: What do you think of the Shanghai government's subsidies for people with intellectual disabilities?

Wife: It's all right, but it would be better if it could be higher.

Wu: No, no, my expectation is not too high, because everything depends on my personal ability. If there is 5,000 yuan in front of you, you have to have the ability to do the work. Now I am making a salary of 1,500 yuan a month, plus the Shanghai government's subsidy for my child.

Wife: It is not enough to feed our child in a family of three with a household income of 1,500, so the government gives us a child-support subsidy of 1,000 yuan.

Mother: And there is a new low-income subsistence allowance this year, so that for child support there's actually a total of 1,300 yuan in subsidy, plus Fangmiao Wu's 1,500 yuan, altogether 2,800 yuan a month, but still not enough.

Wife: We don't pay for food and shelter here, it's all on my parents-in-law. I do not have to worry about my child's support, but I do not make money because I'm not working, and I get everything from them.

Q: Okay, that's all for today's interview. I'm sorry I have disturbed you for so long time. Thank you for sharing.

\section{Interview with Fangmiao Wu's Supervisor}

Interviewee: Sunshine Workshop Supervisor

Interviewer and writer: Jiaying Shen

Interview date: December 26, 2016 
Interview place: Sunshine Workshop, Shanghai

Q: When did you come to know Fangmiao Wu? What are your impressions of him?

Supervisor: I only started to work here in April this year, and Fangmiao $\mathrm{Wu}$ started in November 2013. Before I came here, another supervisor was responsible for everything, so I am not very clear about the situation at that time. As for me, I think he is pretty good, but I am not able to tell you anything regarding what he was like before. Although we have archived records, all the files are now sealed up, and there would be a lot of hassle if you requested a reading.

Q: Oh, I see. What do you know about the working hours and salary of Fangmiao $\mathrm{Wu}$ and others?

Supervisor: 1,495 yuan per month, not based on days or hours of work; as long as they attend as scheduled in a month, they get their money. They work Monday through Friday, 2 to 4 p.m. in the afternoon, and they don't have to work on weekends and holidays. If their task is finished early sometimes, or if the weather is terrible, I will let them go home early. For instance, it is raining today, and they come early, all arriving at 1:15, so I'll let them go home at 3 o'clock, in case the rain becomes worse. Yes, they are not the same as us, and they have no flexible days off. Sometimes we will work on Saturday or Sunday to rest on holidays, but they have problems with that. Even if there is a schedule switch, they don't work on weekends, and they can still take a rest on holidays.

Q: As I observed, they are grouped for work, right?

Supervisor: Yes, they are divided into four groups to fold the soap instruction sheets. Fangmiao $\mathrm{Wu}$ is in Team 2. The working pace is different between groups. Team 1 over there, the team sitting in the row next to Fangmiao $\mathrm{Wu}$, is the fastest at folding. Fangmiao Wu's team folds the second fastest, and now only these two teams have finished folding, so their team members can go home first. The other people, who are relatively slow, will stay here for now, and after they finish, they can go back home. There is no fixed amount of work for them every day, and I haven't calculated yet, but they can fold up to four or five bundles of soap instruction sheets in one day. The workload for each team is the same, but their speed varies.

Q: Okay, what shortcomings do you think Fangmiao Wu has, if any, and what are your expectations of him?

Supervisor: No, no, Fangmiao Wu is quite good, and I don't think he has any shortcomings. He's doing very well now.

Q: Okay. Thank you for sharing. 


\section{Observation of Fangmiao Wu at the Sunshine Workshop}

Observation date: 13:15-15:00, December 26, 2016

Observation place: Sunshine Workshop, Shanghai

Observer and writer: Jiaying Shen

Because of rain, Fangmiao Wu and others started work at 13:15, and went home early at 15:00 after they completed their tasks.

\begin{tabular}{|c|c|c|}
\hline Time & Work observed & Remarks \\
\hline $13: 15$ & $\begin{array}{l}\text { Arrives at the Sunshine Workshop, sits } \\
\text { down in his seat, ready for work }\end{array}$ & \\
\hline 14:00 & Folds soap instruction sheets & $\begin{array}{l}\text { Working very skillfully, Fangmiao Wu } \\
\text { first folds some A4-sized soap instruction } \\
\text { sheets vertically several times, and then } \\
\text { presses the narrow slips to make them } \\
\text { smooth with his fingers. Many of his } \\
\text { colleagues like to fold one sheet at a time, } \\
\text { while Fangmiao Wu likes to put a number } \\
\text { of sheets in his hand and folds them all } \\
\text { together }\end{array}$ \\
\hline 14:03 & Folds soap instruction sheets & \\
\hline 14:06 & Folds soap instruction sheets & $\begin{array}{l}\text { Chats with colleagues, talking and } \\
\text { laughing }\end{array}$ \\
\hline 14:09 & Folds soap instruction sheets & $\begin{array}{l}\text { Chats with colleagues, talking and } \\
\text { laughing }\end{array}$ \\
\hline 14:12 & Folds soap instruction sheets & $\begin{array}{l}\text { Chats with colleagues, talking and } \\
\text { laughing }\end{array}$ \\
\hline $14: 15$ & Folds soap instruction sheets & \\
\hline $14: 18$ & Folds soap instruction sheets & $\begin{array}{l}\text { Chats with colleagues, talking and } \\
\text { laughing }\end{array}$ \\
\hline $14: 21$ & Folds soap instruction sheets & \\
\hline 14:51 & Folds soap instruction sheets & $\begin{array}{l}\text { Chats with colleagues, talking and } \\
\text { laughing }\end{array}$ \\
\hline $14: 25$ & Folds soap instruction sheets & \\
\hline $14: 34$ & Folds soap instruction sheets & $\begin{array}{l}\text { Chats with colleagues, talking and } \\
\text { laughing }\end{array}$ \\
\hline $14: 37$ & Folds soap instruction sheets & \\
\hline 14:41 & Folds soap instruction sheets & \\
\hline $14: 45$ & Folds soap instruction sheets & $\begin{array}{l}\text { Team } 1 \text { sitting next to him has completed } \\
\text { today's work tasks. Fangmiao Wu calmly } \\
\text { and slowly folds the sheets in his hands, } \\
\text { discussing with his colleagues the tour on } \\
\text { New Year's Day }\end{array}$ \\
\hline
\end{tabular}


(continued)

\begin{tabular}{c|l|l}
\hline Time & Work observed & Remarks \\
\hline $14: 50$ & $\begin{array}{l}\text { Fangmiao Wu's Team 2 has also } \\
\text { completed today's work }\end{array}$ & $\begin{array}{l}\text { Fangmiao Wu puts his folded soap } \\
\text { instructions sheets into the storage box on } \\
\text { the table }\end{array}$ \\
\hline $14: 52$ & Team 2 hands in the work results & \\
\hline $14: 53$ & Off work & \\
\hline
\end{tabular}

Translated by Zheng Si Edited by Andy Boreham and Zijian Chen

Open Access This chapter is licensed under the terms of the Creative Commons AttributionNonCommercial-NoDerivatives 4.0 International License (http://creativecommons.org/licenses/bync-nd/4.0/), which permits any noncommercial use, sharing, distribution and reproduction in any medium or format, as long as you give appropriate credit to the original author(s) and the source, provide a link to the Creative Commons license and indicate if you modified the licensed material. You do not have permission under this license to share adapted material derived from this chapter or parts of it.

The images or other third party material in this chapter are included in the chapter's Creative Commons license, unless indicated otherwise in a credit line to the material. If material is not included in the chapter's Creative Commons license and your intended use is not permitted by statutory regulation or exceeds the permitted use, you will need to obtain permission directly from the copyright holder.

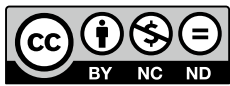

